\title{
Tymoteusz Król
}

\section{Polski patriota z niemieckiej kolonii. Analiza tekstów hagiograficznych o Józefie Bilczewskim}

\section{Wprowadzenie}

W ilamowice, małe miasto leżące na pograniczu Śląska i Małopolski, zostało założone w XIII wieku przez przybyłych z zachodu osadników. Przywieźli ze sobą, używany do dzisiaj w Wilamowicach, germański język wymysiöeryś. Na temat ich dokładnego pochodzenia powstało wiele teorii opisanych już przez językoznawców i etnologów. Najbardziej popularna wśród mieszkańców jest ta o flamandzkim pochodzeniu założycieli (Filip, 2005; Wicherkiewicz, 2003). Innymi wyznacznikami odrębności etnicznej Wilamowian są, oprócz języka i mitu wspólnego pochodzenia, strój, świadomość własnej odrębności (zarówno od Niemców, jak i Polaków) oraz łącząca ich wspólnota pamięci. Wilamowianie, mimo swojej odrębności, starali się okazywać lojalność wobec każdego organizmu państwowego. Być może dzięki temu udało im się tak długo zachować odrębność.

\footnotetext{
${ }^{1}$ Praca naukowa finansowana ze środków budżetowych na naukę w latach 2016-2022 jako projekt badawczy w ramach Diamentowego Grantu. Tytuł projektu: „Góry, pagórki, przykryjcie nas - Wilamowianie wobec powojennych prześladowań”.
} 
Oprócz rolnictwa Wilamowianie zajmowali się również tkactwem i handlem, a podczas podróży do licznych europejskich miast bogacili się oraz kształcili. W Madrycie, Grazu i Wiedniu mieli nawet swoje składy materiałów. To ostatnie miasto miało dla Wilamowian szczególne znaczenie. Podróżowali do niego i osiadali w nim tak licznie, że powstała tam wilamowska kolonia. Wielu Wilamowian kończyło tam różne kursy czy szkoły zawodowe, wyuczając się stolarstwa, ciesielstwa lub innych zajęć rzemieślniczych, którymi zajmowali się później w Wilamowicach (Król, 2020). Kolonia wiedeńska wspierała Wilamowian w Wilamowicach, przesyłając im pieniądze oraz cenne towary do własnego użytku i sprzedaży. Wielu Wilamowian posyłało swoje dzieci do szkół i na studia do Wiednia. Wielu z nich osiągnęło wpływowe pozycje, zwłaszcza osoby decydujące się na karierę duchowną. Część z nich powracała do Wilamowic, gdzie tworzyła warstwę inteligencką. Oprócz inteligencji istniały w Wilamowicach warstwy społeczne - takie jak handlarze, wielcy gospodarze, mali gospodarze i służący - w ramach których zawierano małżeństwa. Dzięki handlowi Wilamowianie znacznie się wzbogacili, co umożliwiło w 1808 roku wykupienie się z poddaństwa, a dziesięć lat później otrzymanie przez Wilamowice praw miejskich.

W Wilamowicach panowała wielojęzyczność. Podstawowym językiem komunikacji był wymysiöeryś. Według różnych źródeł do 1875 roku używano go w różnym stopniu również w kościele i w szkole (Latosiński, 1909, s. 265; Rosner, 1977, ss. 384-385), a w niektórych wypadkach w urzędzie nawet do roku 1939. W sklepach, na targu i na poczcie wilamowszczyznę można było usłyszeć aż do roku 1945 (Neels, 2012). Zachowane dokumenty gminne sporządzane były od XVII wieku głównie w języku polskim, a w XIX wieku częściowo również w języku niemieckim. Listy pisano głównie po niemiecku, czasem po polsku, rzadziej po wilamowsku. Jednak od drugiej połowy XIX wieku w oficjalnych sytuacjach wymysiöeryś wypierany był przez języki niemiecki i polski. To nimi Wilamowianie posługiwali się także podczas kontaktów z okoliczną ludnością, szczególnie handlowych. Większość Wilamowian była więc trójjęzyczna, niektórzy znali również jidysz, gdyż Wilamowice zamieszkiwali na przełomie XIX i XX wieku także Żydzi.

Od XIX wieku w Wilamowicach toczyły się spory ideologiczne na temat tożsamości i języka. Polacy i Niemcy usiłowali różnymi środkami wpłynąć na Wilamowian, żeby zrezygnowali ze swojej odrębnej wilamowskiej tożsamości i języka oraz stali się Niemcami lub Polakami (Filip, 2005). Ostatecznie w okresie międzywojennym, zarówno w szkole, jak i w kościele, na stałe zapanował język polski, język niemiecki nauczany był jako obcy. Wilamowski pozostał 
jednak językiem codziennej komunikacji, a jego wysoki status ciągle utwierdzali wykształceni Wilamowianie mieszkający poza swoją miejscowością, również duchowni, którzy podczas wizyt w Wilamowicach mówili po wilamowsku. Silna była także wilamowska tożsamość, konstruowana w opozycji zarówno do niemieckości, jak i polskości.

Ta wielojęzyczność i wielokulturowość ostatecznie została zniszczona przez wojnę oraz powojenne prześladowania. Pamięć o tych wydarzeniach oraz udziale w nich mieszkańców okolicznych wsi jest żywa w opowieściach starszych i młodszych Wilamowian, zwłaszcza w kontekście procesu wymierania języka i porzucania wilamowskiego stroju. Ich zdaniem do podpisania Volkslisty zostali zmuszeni, a z wyższego statusu w czasie okupacji korzystali, aby pomagać Polakom. Po wojnie zostali jednak potraktowani jak Niemcy, byli wysiedlani i wywożeni do obozów na terenie Polski i ZSRR, a za używanie języka i stroju wilamowskiego groziły surowe kary (Fic i in., 2018; Filip, 2005; Król, 2018).

W latach 50. XX wieku zaprzestawano przestrzegania tych zakazów, w Wilamowicach założono zespół regionalny, który wykorzystywał stroje i melodie do propagowania Wilamowic. Z czasem stał się on wizytówką lokalnych władz, a tkaniny ze wzorami wilamowskimi produkowane były na masową skalę przez Cepelię. W latach 90. zmarły ostatnie kobiety, które nosiły strój wilamowski na co dzień, przez co coraz bardziej przeobrażał się on w kostium zespołu folklorystycznego, podobnie jak język, w coraz mniejszym stopniu był narzędziem codziennej komunikacji.

Dzięki zaangażowaniu młodzieży pod koniec pierwszej dekady XXI wieku zapoczątkowano oddolny program rewitalizacyjny, który od 2014 roku regularnie wspierany jest przez Wydział „Artes Liberales" Uniwersytetu Warszawskiego. W jego wyniku język wilamowski jest znów używany wśród części wilamowskiej młodzieży (Król i in., 2017).

W artykule skupię się na problemie instrumentalizacji tożsamości Wilamowian przez autorów biografii pochodzącego z Wilamowic świętego katolickiego, arcybiskupa Józefa Bilczewskiego (1860-1923). Wydano na jego temat wiele publikacji hagiograficznych oraz naukowych, w których przedstawiany jest jako polski patriota, a okres dzieciństwa i dorastania w Wilamowicach został w nich potraktowany instrumentalnie jako dowód jego polskości. Celem tego tekstu nie jest podważanie polskiej tożsamości arcybiskupa Bilczewskiego, ale obrazu Wilamowic jako typowo polskiej miejscowości oraz podanie w wątpliwość dotąd niekwestionowanego obrazu rodziców duchownego jako polskich patriotów. Moim zdaniem w biografiach Bilczewskiego pomijana jest (być może celowo) specyfika wielowymiarowej tożsamości Wilamowian. 


\section{Inspiracje teoretyczne i materiał źródłowy}

Choć etnolodzy pozyskują swój materiał głównie podczas badań terenowych, również źródła literackie mogą być materiałem do analiz, gdyż pełne są „wyobrażeń, stereotypów i mitów czerpanych z szerokiego spektrum społecznych światów" oraz zawierają w sobie "niekwestionowane bogactwo potocznej wiedzy i konwencjonalnych mądrości" (Hammersley \& Atkinson, 2000, s. 167). Do badania tych wyobrażeń używam pojęcia „toposu” oraz aparatu analitycznego stosowanego przez folklorystów podczas analizy opowieści ustnych. Kiedy raz opowiedziana opowieść wspomnieniowa przekazywana jest dalej, odrywa się od konkretnego narratora (najczęściej świadka wydarzenia) i podlega obiektywizacji narracji, po czym tworzone są jej różne warianty. Proces ten nazywa się fabularyzacją i folkloryzacją. W jego efekcie powstaje "nowa jakościowo, sfabularyzowana już narracja, którą nazywamy fabulatem”, będąca jest już nową, wspólnotową wersją opowieści (Hajduk-Nijakowska, 2016, s. 65). Opowieść świadka ulega "dopracowaniu” przez grupę, a jej ostateczna forma jest ściśle związana z potrzebami grupy i reprezentuje wspólnotową, akceptowalną dla wszystkich interpretację wydarzeń (Hajduk-Nijakowska, 2016, s. 65). Efektem procesów folkloryzacji i fabularyzacji jest „powtarzalność, a zarazem zmienność (wariantywność) opowieści” (Grochowski, 2019, ss. 22-23). Spróbuję pokazać, że w biografiach Bilczewskiego opowieści zaczerpnięte z tekstów pierwszych hagiografów, choć nie były przekazywane drogą ustną, to wskutek cytowania przez kolejnych autorów, ulegały fabularyzacji i folkloryzacji. Potrzebą grupy (polskich hagiografów oraz czytelników), do której dostosowywano opowieść, było wzmocnienie toposu Polaka-katolika obecnego w nacjonalistycznym dyskursie stosowanym przez niektórych autorów biografii. Pojęcia nacjonalizmu używam za Krzysztofem Jaskułowskim „w szerokim i neutralnym znaczeniu odnoszącym się do całokształtu problematyki narodowej, w szczególności do pewnego typu ideologii narodowej, narodu i państwa narodowego, narodowej symboliki, ruchu narodowego, a także tożsamości narodowej" (Jaskułowski, 2013, s. 23).

Józef Biba urodził się 26 kwietnia 1860 roku w Wilamowicach. Po ukończeniu gimnazjum w Wadowicach i zdaniu egzaminu dojrzałości w 1880 roku wstąpił do seminarium i rozpoczął studia na Wydziale Teologii Uniwersytetu Jagiellońskiego. W 1884 roku przyjął święcenia kapłańskie. 30 listopada 1885 roku zmienił nazwisko na Bilczewski. W 1886 roku spędził rok w Wiedniu, doktoryzował się z teologii. Przez kolejne lata studiował w Rzymie i Paryżu. W 1891 roku habilitował się na Uniwersytecie Jagiellońskim z teologii fundamen- 
talnej, w tym samym roku został profesorem nadzwyczajnym dogmatyki specjalnej na Wydziale Teologicznym Uniwersytetu Lwowskiego, a dwa lata później otrzymał nominację na profesora zwyczajnego. Następnie pełnił funkcje dziekana, prodziekana, a w 1900 roku został powołany na rektora Uniwersytetu Lwowskiego, ale objął to stanowisko na krótko, gdyż w tym samym roku został arcybiskupem. Zasłynął z dużej regularności wizytowania parafii, budowy 328 kościołów i kaplic, wspierania oraz zakładania nowych zgromadzeń zakonnych. Zmarł 20 marca 1923 roku we Lwowie. Został beatyfikowany 26 czerwca 2001 roku, a kanonizowany 23 października 2005 roku. Podczas obu procesów zwracano uwagę na nacisk, jaki kładł na rozwój kultu eucharystyczny i maryjny (Schauber \& Schindler, 2008, s. 80; Wołczański, 2003).

Biografie Bilczewskiego można podzielić na hagiograficzne i naukowe. Te pierwsze, z racji specyfiki gatunku, zakładają mitologizację postaci. Drugie, nawet jeśli pisane przez autorów pracujących na uczelniach i deklarujących naukowy charakter publikacji, czasem również powielały hagiograficzne fabulaty. Dlatego warto chronologicznie prześledzić powstawanie tych prac, aby móc później wychwycić pierwotne relacje, które potem zostały sfabularyzowane i sfolkloryzowane.

Pierwsza biografia Bilczewskiego znalazła się w Monografii miasteczka Wilamowic pióra miejscowego nauczyciela, Józefa Latosińskiego² (Latosiński, 1909, ss. 328-351). W rozdziale zatytułowanym „Życiorysy rodaków wilamowickich, Kościołowi i Ojczyźnie zasłużonych" opisał on krótkie (najczęściej kilkuzdaniowe) biogramy kilkudziesięciu Wilamowian, natomiast Bilczewskiemu poświęcił ponad 20 stron. Zdecydowałem się na dokładniejszą analizę tego tekstu, ponieważ wspomniana monografia miała zasięg szerszy niż lokalny, a jej autor nie był Wilamowianem. Zaangażował się za to w działalność Ruchu Narodowego, przez co nie był w Wilamowicach lubiany. Jak wspominał jeden z moich rozmówców, Och Latosiński, Latosiński, koledzy nawet na pogrzeb mu nie przyszli, a wiesz dlaczego? Bo był narodowcem (por.Zajączek, 1929, s. 10). Głównym celem pracy, oprócz prezentacji wielu cennych, niedostępnych już dzisiaj dokumentów, było przekonanie Wilamowian do polskości. Życiorys pochodzącego z Wilamowic duchownego miał być kolejnym krokiem ku realizacji politycznych celów autora:

Jak długa i szeroka polska ziemia, wszędzie zabrzmiała wiadomość o tej nominacyi radosnem echem i poruszyła do głębi serca rodaków. Stuletnią niewolą znękany naród

\footnotetext{
${ }^{2}$ Latosiński przybył do Wilamowic z Czchowa w latach 80. XIX wieku.
} 
odetchnął pełniejszą piersią, ciesząc się, że Opatrzność Boża w nieprzebranej dobroci Swej zsyła mu za przewodnika męża-kapłana, który jako patryota-apostoł na swem wysokiem stanowisku nie zapomni, że ta polska ziemia go zrodziła i pod hasłem „Bóg i Ojczyzna" poprowadzi wszystkie stany drogą wiary i pracy do lepszej przyszłości, mającej na celu odrodzenie narodu, kiedy zabłyśnie upragniona wolności jutrzenka (Latosiński, 1909, s. 334).

Tekst ten, podobnie jak cała monografia, przesiąknięty jest dyskursem nacjonalistycznym, typowym dla wyznawanej przez autora ideologii Narodowej Demokracji, utożsamiającej polskość z katolicyzmem (por. Jaskułowski, 2013, s. 40). Informacje zawarte w tej pracy wymagałyby więc krytycznego komentarza, jednak przez większość biografów Bilczewskiego cytowana była ona bezkrytycznie.

Kolejną biografię autorstwa ks. Mieczysława Tarnawskiego wydano rok po śmierci Bilczewskiego, a jej reprint - w 1991 roku. O książce tej współczesny badacz biografii naukowej arcybiskupa, Józef Kałużny, pisał: „Zrozumiały szacunek, jakim ks. Tarnawski darzył swego biskupa, może być powodem, dla którego jego opracowaniem rządzi momentami licentia poetica, dodająca blasku postaci wielkiego arcypasterza" (Kałużny, 2015, s. 53). Nieścisłości dopatrzyli się zapewne już redaktorzy reprintu, którzy zdecydowali się na jego ocenzurowanie. Jak zapewnili w komentarzu we wstępie, o pominięciu ,jednego obszernego fragmentu dotyczącego poglądów politycznych Arcybiskupa” zdecydowano „w przekonaniu, że byłby niezrozumiały dla ogółu czytelników" (Tarnawski, 1991, s. 5) ${ }^{3}$. To z tego tekstu korzystał zapewne autor kolejnej hagiografii Bilczewskiego, Wincenty Urban (Urban, 1977), a także autorzy licznych prac powstałych po jego beatyfikacji i kanonizacji. Najważniejsze z nich to prace z serii Święci sq wśród nas (Machniak, 2001) oraz Wielcy ludzie Kościoła (Dziedzic \& Dziedzic, 2012). Mniejsze teksty pojawiały się również w zbiorach biogramów świętych bądź dostojników kościelnych (Prokop, 2010) ${ }^{4}$. Ważnym źródłem dla współczesnych hagiografów były prace historyków, szczególnie Józefa Wołczańskiego (Wołczański, 2003) i Urszuli Perkowskiej (Perkowska, 2003). Jak wykazała moja analiza, teksty krakowskiej historyczki, choć potwierdzone autorytetem naukowym autorki, zawierały zniekształcenia i nieścisłości, które zostały później sfabularyzowane i sfolkloryzowane w tekstach późniejszych autorów.

W ostatnich latach powstały rzetelne prace naukowe, wśród których na uwagę zasługuje zbiór dokumentów z procesu beatyfikacyjnego duchownego, zawierający wspomnienia na

\footnotetext{
${ }^{3}$ Fragment ten dotyczył stosunków polsko-ukraińskich.

${ }^{4}$ Prokop powołał się na Tarnawskiego, Urbana i Machniaka.
} 
jego temat, zebrane przez Józefa Wołczańskiego (Wołczański, 2016), oraz obszerna i wnikliwa biografia naukowa autorstwa Józefa Kałużnego (Kałużny, 2015). Niestety praca ta, w której autor krytycznie przyjrzał się powielanym w poprzednich publikacjach nieścisłościom, obejmuje głównie lata 1885-1900, a więc okres mniej interesujący dla tematu tego artykułu.

Zanim przejdę do analizy, chciałbym zwrócić uwagę, że biografowie mieli na celu nie tylko pokazanie świętości Bilczewskiego, ale również jego polskości: „Jego życie jest wpisane w trudne dzieje Ojczyzny, która walczyła o swoją tożsamość religijną i narodową" (Machniak, 2001, s. 9), „Jako gorący patriota reprezentował polską rację stanu, opowiadając się za odrodzeniem Ojczyzny w jej historycznych granicach przy zachowaniu integralności terytorialnej" (Wołczański, 2003, s. 20). Powielanie tych samych błędów i nieścisłości w kolejnych publikacjach jest przykładem fabularyzacji, folkloryzacji i dostosowywania opowieści do potrzeb grupy: toposu „świętego Polaka”, związanego z toposem „Polaka katolika”, który stał się „emblematem polskiego nacjonalizmu” (Kubica, 2011, s. 69). Hagiografowie przemilczeli fakt, że święty Józef Bilczewski jako dziecko mieszkał w miejscowości, gdzie większość mieszkańców, być może również i on, miała wielowymiarową, a nawet niepolską tożsamość i ojczysty język inny niż polski.

\section{(Nie)zamożność rodziny}

Ojciec późniejszego arcybiskupa, Franciszek Biba pochodził z rodu Biöetuł-Mocków a matka z Fajkiszów. Latosiński pisał: „Ojciec, posiadający szczupły majątek, zajmował się oprócz rolnictwa ciesielstwem, a zatrudnieniem matki było gospodarstwo domowe, oraz wychowanie licznego rodzeństwa" (Latosiński, 1909, ss. 328-329). Biedę w domu Bibów podkreślali w biografiach Józefa Bilczewskiego kolejni autorzy: „Ojciec - ubogi rolnik i cieśla” (Tarnawski, 1991, s. 9), „Ojciec Józefa Bilczewskiego Franciszek posiadał niewielkie gospodarstwo rolne (ok. 6 morgów ziemi). Nie mogąc utrzymać licznej rodziny dorabiał również jako cieśla” (Machniak, 2001, s. 13). Prokop pisał, że rodzice arcybiskupa „posiadali niewielkie gospodarstwo rolne, a ponadto ojciec przyszłego arcybiskupa trudnił się ciesielstwem" (Prokop, 2010, s. 341).

Tymczasem przy chrzcie Józefa Biby z 29 kwietnia 1860 roku widnieje informacja, że jego ojciec Franciszek Biba spod numeru 10, był kmieciem, a więc posiadał znacznie więcej

\footnotetext{
${ }^{5}$ Ponieważ w wyniku endogamii w Wilamowicach powtarzały się te same nazwiska, aby umożliwić identyfikację konkretnej osoby funkcjonował system przydomków przypisanych do poszczególnych rodów.
} 
niż wspomniane 6 morgów pola ${ }^{6}$ (Liber vitorum, 1831-1868, s. 338). Potwierdzają to również badania historyka Konrada Meusa, który wymienia go w wykazie podatników z 1867 roku "[w] grupie płatników najwyższych podatków, a więc faktycznie ludzi mogących pochwalić się najlepszą kondycją majątkową wśród wilamowskich mieszczan". Zdaniem historyka tworzyli oni "elitę ekonomiczną miasteczka” (Meus, 2018, s. 58). Najprawdopodobniej informacja o 6 morgach pola, której źródła Machniak nie podał, pochodziła z Pamiętników Eugeniusza Bilczewskiego?. Autor pisał tam, że jego ojciec kupił od swojego ojca (a więc Franciszka) gospodarstwo o powierzchni 6 morgów (Bilczewski, b.d., s. 32). Mowa tutaj jednak o roku 1903, kiedy blisko siedemdziesięcioletni Franciszek zapisał zapewne inne części gospodarstwa innym dzieciom. Dlatego też stwierdzenie, że Franciszek Biba nie mógł utrzymać licznej rodziny wydaje się być stworzonym na wyrost. O zamożności Biöetuł-Mocków na tle innych wilamowskich rodzin w tym czasie świadczy również istnienie fotografii z lat 70. XIX wieku, na której widoczna jest cała rodzina (Wołczański, 2016, s. 429), a także fakt, że Józef nie był jedynym dzieckiem, które posłano do dalszej nauki. Jego brat Jan (ur. 1863) kształcił się w Wiedniu na bednarza i po powrocie założył własną gospodę, Stanisław (ur. 1870) kształcił się w Wiedniu na stolarza i założył po powrocie własną stolarnię, a najmłodszy Kazimierz również kształcił się w Wiedniu na stolarza, a następnie został sekretarzem gminnym (Bilczewski, b.d., ss. 13-19). Aby nadać wiarygodności biedzie w domu Bibów, podkreślano ich wielodzietność (por. Latosiński, 1909, s. 329). Jednak również i ten argument nie jest przekonujący, gdyż dzieci Franciszka i Anny Bibów rodziły się z dość dużymi przerwami, a między Józefem i jego najmłodszym bratem była różnica 24 lat ${ }^{8}$.

Zapewne z perspektywy polskiej szlachty, z której zazwyczaj wywodzili się wyżsi szczeblem duchowni, rodzina Bibów była biedna, jednak - jak na wilamowskie warunki należeli oni raczej do najbogatszych. E. Bilczewski, choć przyznał w swoich wspomnieniach, że sam arcybiskup twierdził, iż było znacznie więcej bardziej potrzebujących rodzin, napisał:

Jeśli jednak przyjmiemy pochodzenie tego człowieka z naprawdę biednej rodziny chłopskiej, gdzie dom mu nie wiele pomagał (matka sama nie zjadła masła, domownicy nie dostali, oszczędzała, by Józkowi w szkole uciułać czasem ryńskiego (2 korony)

\footnotetext{
${ }^{6}$ Łan kmiecy wynosił około 48 morgów, czyli ponad 26 ha.

${ }^{7}$ Eugeniusz Bilczewski (1894-1970) był bratankiem Józefa, urodził się w Wiedniu, jako dziecko przybył do Wilamowic. Został nauczycielem, później kierownikiem szkoły oraz propolskim, choć bardzo dystansującym się od endecji, działaczem.

8 Jan Stefan (1863 -1953), Franciszek (1867-1910), Stanisław (1870-1942), Anna (1870-1876), Maciej (1874-1874), Katarzyna (1876-1895), Elżbieta Anna (1880-1899), Kazimierz Franciszek (1884-1978) (Wołczański, 2016, s. 5).

9 "Tymczasem stosunek arcybiskupa do rodziny był dość zimny, w każdym razie więcej się rodzina spodziewała niż otrzymywała [...] Biskup zawsze mówił, że dobra arcybiskupie są dla biedniejszych od własnej rodziny" (Bilczewski, b.d., s. 10).
} 
na wydatki), szedł człowiek ten o własnych siłach i tylko pilną nauką doszedł do najwyższej godności kościelnej, a przy tym i świeckiej, bo został rektorem uniwersytetu (Bilczewski, b.d., ss. 11-12).

Autor wspomnień miał tutaj zapewne na myśli fakt, że młody Wilamowianin dzięki swojej ciężkiej pracy osiągnął sukcesy w karierze zawodowej oraz kościelnej. Sfabularyzowane i sfolkloryzowane przez hagiografów historie o biedzie panującej w domu rodzinnym służyły więc wpasowaniu postaci w topos "ubogiego świętego".

\section{Języki dzieciństwa Józefa Biby}

Według literatury (Dziedzic \& Dziedzic, 2012, s. 15; Kałużny, 2015, s. 25; Prokop, 2010, s. 341; Wołczański, 2003, s. 17, 2016, s. 5) Józef uczęszczał do szkoły trywialnej w Wilamowicach w latach 1868-1871. Większość autorów zupełnie pominęła fakt, że nie była to szkoła polskojęzyczna. Kałużny pisał, że

Lata sześćdziesiąte XIX wieku przyniosły na terenie Austro-Węgier złagodzenie polityki narodowościowej, co zaowocowało między innymi wprowadzeniem w 1869 roku ustawy szkolnej, nakazującej nauczanie w szkołach w językach narodowych. Odtąd też edukacja Józefa Biby odbywała się w języku polskim (Kałużny, 2015, s. 26).

Autor nie napisał jednak, w jakim języku edukacja odbywała się wcześniej. Podobnie opisali to Małgorzata i Stanisław Dziedzic (Dziedzic \& Dziedzic, 2012, s. 15).

Zdaniem Latosińskiego „w szkole uczono polskiego i niemieckiego języka, lecz wykład odbywał się w gwarze wilamowickiej, gdyż nauczycielami przez cały prawie wiek (1783-1875) byli rodacy tutejsi" (Latosiński, 1909, s. 265). Wersję taką potwierdzili zarówno badacze niemieccy (Kuhn, 1981, s. 341; Rosner, 1977, ss. 384-385), jak i polscy (Filip, 2005; Wicherkiewicz \& Zieniukowa, 2001, s. 496). E. Bilczewski twierdził nawet, że język niemiecki był językiem urzędowym w szkole do 1885 roku (Bilczewski, b.d., s. 8).

W tym kontekście ważne wydaje się pytanie, czy rzeczywiście Józef Biba rozpoczął edukację w 1868 roku. Autorzy (Prokop, 2010, s. 341) nie powołują się na żadne źródła. Jako jedyny o edukacji Biby pisał Latosiński, który zamieścił wyłącznie informację, że ukończył on W „1871 r. szkołę ludową w Wilamowicach, a 1872 klasę IV normalną w Kętach” (Latosiński, 1909, s. 329; por. Urban, 1977, s. 8). Za Latosińskim informację tę zacytował Urban (Urban, 1977, s. 8), a Tarnawski nie wspomina o latach, w jakich Biba miał uczęszczać do szkoły. 
Ponieważ szkoła ta miała trzy klasy, autorzy zapewne wywnioskowali, że musiał on rozpocząć edukację w 1868 roku, a więc dopiero w wieku 8 lat. Jest więc całkiem możliwe, że naukę zaczął on w roku 1867 i trzyklasową szkołę ukończył w cztery lata, gdyż pierwszy rok zajęła mu nauka języka polskiego, którego nie znał z domu (co było częste wśród Wilamowian). Jest też bardzo prawdopodobne, że przez cały okres edukacji w Wilamowicach jednym z języków nauczania był język wilamowski, a na pewno też język niemiecki.

Języki wczesnej edukacji Biby oraz język domowy wydają się dość istotne w kontekście tego, co autorzy pisali o kolejnych etapach edukacji. Kałużny stwierdził, że Biba

z łatwością wykorzystywał w praktyce znajomość języków podczas studiów, nie tylko uczestnicząc w wykładach prowadzonych w języku niemieckim na UJ czy studiując na uczelniach niemiecko- i francuskojęzycznych (Wiedeń, Paryż), ale również prowadząc w nich bogatą korespondencję (Kałużny, 2015, ss. 26-27).

\section{„Polski duch domu rodzinnego"}

Kolejnym ważnym aspektem, podkreślanym przez hagiografów była postawa patriotyczna wyniesiona z domu. Opisy te pojawiają się głównie w kontekście matki, z którą miała łączyć Józefa szczególna więź. Autorzy rzadko powoływali się na źródła, dlatego trudno powiedzieć, czy zaczerpnęli motyw matki z tekstów arcybiskupa, czy jest to reprodukcja jej szczególnego kultu zapoczątkowanego przez Latosińskiego. W swojej monografii pisał, że „Bilczewska Anna [...] jaśniała cnotami pobożności i pracowitości, okazując otoczeniu rzadką dobroć, uprzejmość i miłosierdzie. Zalety powyższe, przebijające się w szczególnej szlachetności serca i w delikatności postępowania, cechowały jej charakter" (Latosiński, 1909, ss. 348-349). Na uwagę zasługuje fakt, że w swojej książce zamieścił zdjęcie matki Józefa i opisał jej życiorys szerzej niż kilkudziesięciu innych Wilamowian. Była to zapewne strategia mająca na celu przekonanie Wilamowianek do polskości: „Podane niżej szczegóły z życia Anny Bilczewskiej, umieszczone ku nauce i zbudowaniu matek i dzieci wilamowickich, dowodzą bezgranicznej miłości jej ku swemu rodzeństwu i stawiają ją jako wzór postępowania dla tutejszych pokoleń" (Latosiński, 1909, s. 350). Wśród zasług tej postaci wymienił nauczenie dzieci pacierza polskiego ${ }^{10}$. Utrzymaniu

\footnotetext{
${ }^{10}$ Anna Biba urodziła się w 1842 roku w Wilamowicach, w domu nr 125. Według niektórych przekazów jej ojciec był organistą i nauczycielem w szkółce niedzielnej poza Wilamowicami, co mogło wpłynąć na jej postawę wobec języka i tożsamości polskiej.
} 
spójnej wizji jej polskości posłużyło zapewne zmanipulowanie jej nazwiska: nigdy nie zmieniła ona nazwiska na Bilczewska i zmarła jako Anna Biba. Następnie opisał kilka historii świadczących o jej chorobie i uzdrowieniach, a także o tym, że modliła się ona na ścieżkach, które wydeptał, odmawiając brewiarz w ogrodzie, jej syn (Latosiński, 1909, s. 351)"11. Słowa Latosińskiego były wielokrotnie parafrazowane przez kolejnych autorów (Machniak, 2001, s. 13; Urban, 1977).

Znacznie mniej miejsca biografowie poświęcają ojcu. Ponownie może to wynikać z jednej strony z postawienia takiego akcentu przez Latosińskiego, z drugiej zaś ze słów samego arcybiskupa, który według Tarnawskiego napisał w swoim testamencie w 1917 roku: „Bóg dał mi bardzo wiele, bo łaskę świętej wiary katolickiej i dobrą matkę, która jej zasiew rozwijała w duszy mojej tak, iż jej w życiu nie utraciłem" (Tarnawski, 1991, s. 8). Ojciec najczęściej jest pomijany lub marginalizowany poprzez podkreślanie szczególnego związku z matką (por. Koperek, 2003, s. 73). Tarnawski wspomniał co prawda, że Biba urodził się w "starej osadzie niemieckiej", ale dodał: „W skromnym domu rodziców Arcybiskupa panował jednakowoż niepodzielnie duch polski, a krzewicielką jego była najlepsza matka Arcypasterza" (Tarnawski, 1991, s. 8). Podkreślił także, że Bilczewski „z pochodzenia był synem ludu ziemi krakowskiej” (Tarnawski, 1991, s. 8). Na potwierdzenie swoich słów zacytował fragment jego listu pasterskiego:

Zarzucano mi moje pochodzenie z osady niemieckiej. A przecież moja dobra matka mówiła ze mną tylko pacierz polski i jako pierwszą książkę objaśniała mi polską biblię. Kiedy wstąpiłem do gimnazjum w Wadowicach, jam, chłopczyna dwunastoletni, wypisał w rodowodzie szkolnym, że jestem narodowości polskiej. Chyba nie dla kariery (Bilczewski, 1924, s. 6).

Zamieszczony poniżej komentarz, że o „zarzucaniu mu niemieckości” arcybiskup mawiał „z bólem, który przygniatał jego serce” (Tarnawski, 1991, s. 8), został dodany przez autora biografii zgodnie ze stosowanym przez niego nacjonalistycznym dyskursem. Czy rzeczywiście takie były odczucia Bilczewskiego? Tego nie wiemy.

Tarnawski i Machniak pisali, że Bilczewski był Polakiem, mimo że Wilamowice były osadą niemiecką. Tymczasem niektórzy autorzy, aby podkreślić polskość arcybiskupa, próbowali dowieść polskości Wilamowic. Perkowska pisała, że język wilamowski choć „[W]ywodzący się z dialektów starogermańskich, [...] uległ w ciągu dziesięcioleci na skutek wpływu otoczenia znacznym przekształceniom. Zachował wszakże własną odrębność powodującą, że jest zupełnie niezrozumiały tak dla współczesnego Niemca, jak i dla Polaka" (Perkowska, 2003,

\footnotetext{
${ }^{11}$ Opowieść o matce modlącej się na ścieżkach wydeptanych przez syna księdza autor zaczerpnął zapewne z listów Bilczewskiego. Nie ma jednak pewności, że chodziło o samego Bilczewskiego i jego matkę (por. Wołczański, 2016, s. 27).
} 
s. 132). Podkreślenie przez autorkę dystansu języka wilamowskiego (którym, jak przyznała, posługiwała się w domu rodzina Bibów) do niemieckiego sugeruje dystans Wilamowian do Niemców, a więc umożliwia uznanie ich za Polaków. Perkowska napisała, że „w szkole i urzędach [mówiło się] częściowo po niemiecku, częściowo po polsku, ale w kościele po łacinie i po polsku" (Perkowska, 2003, s. 132), co znacznie rozmija się z podanymi wcześniej informacjami z literatury. Podkreślenie, że w kościele oprócz łaciny używany był język polski, choć w szkole stosowano i niemiecki, i polski jest przejawem opisywania Wilamowic w ramach dyskursu polsko-katolickiego, podobnie jak fragment o tożsamości Wilamowian:

[M]ieszkańcy Wilamowic wyróżniali się większą zamożnością oraz poczuciem pewnej dumy i wyższości z uwagi na własną nieco odmienną tożsamość. Mimo swojej odrębności językowej i obyczajowej, mieszkańcy miasteczka uważali się za Polaków. Jednym z dowodów tego są ich własnoręczne wpisy w kartach uniwersyteckich, gdzie w latach zaborów ale również później, wszyscy wilamowiczanie konsekwentnie wpisywali narodowość polską i język ojczysty polski (Perkowska, 2003, s. 132).

Jak wykazała moja kwerenda w Archiwum Uniwersytetu Jagielońskiego, na które powołuje się autorka, choć wśród wilamowskich studentów (Meus, 2018, ss. 123-124) ${ }^{12}$ pojawiały się również pojedyncze deklaracje narodowości niemieckiej, a więc nie jest prawdą, że "wszyscy” Wilamowianie „konsekwentnie” deklarowali się jako Polacy. Należy również pamiętać, że wybierając się na studia, mieli oni za sobą już kilkanaście lat edukacji w polskiej szkole, w tym w gimnazjach poza Wilamowicami, więc byłby to dowód na deklarowanie narodowości przez pochodzących z Wilamowic studentów studiujących na polskich uczelniach (a niektórzy wybierali przecież niemieckie), a nie na to, że wszyscy mieszkańcy „uważali się za Polaków”, jak pisała Perkowska.

Kombinację argumentów Tarnawskiego i Perkowskiej (o języku niezrozumiałym dla Niemców i krzewiącej polskość matce) stanowi rozdział "Pochodzenie i młodość" w książce Małgorzaty i Stanisława Dziedziców. Autorzy użyli bezrefleksyjnie określeń typowych dla polskiego dyskursu nacjonalistycznego, lecz nieoczy wistych w kontekście wilamowskiej wielokulturowości i wielojęzyczności. Po zacytowaniu wspomnianego już fragmentu listu Bilczewskiego o matce napisali:

Bez wątpienia, w warunkach zaboru austriackiego, mimo wprowadzonej niedawno autonomii galicyjskiej, nie sposób było mówić o takich preferencjach dla ludności pol-

\footnotetext{
${ }^{12}$ Wykaz osiemnastu studentów Uniwersytetu Jagiellońskiego z lat 1863-1918 urodzonych w Wilamowicach zamieścił w swojej pracy Konrad Meus (Meus, 2018, ss. 123-124).
} 
skiej, a w świadomości ogółu Polaków zamieszkujących te ziemie pozostawały wciąż tak nieodległe czasy wściekłej antypolskiej polityki władz wiedeńskich, rugujących język polski z życia publicznego. Twierdzami polskości były wówczas Kościół, dom i język ojczysty. W przypadku mieszkańców Wilamowic wspomniany już dialekt, którym posługiwano się na co dzień, był nie tylko świadectwem ich tożsamości, odrębności, ale i poczucia przynależności narodowej (Dziedzic \& Dziedzic, 2012, s. 13).

W przypadku Wilamowic ani kościół, ani dom, ani język ojczysty nie były „twierdzami polskości". Określenie "język ojczysty" bez doprecyzowania jaki oraz militarne słownictwo, jak „twierdza”, są typowymi cechami dyskursu nacjonalistycznego. Intrygujące jest, w jaki sposób język wilamowski, nazwany przez autorów dialektem, miałby być „świadectwem poczucia przynależności narodowej" - w domyśle polskiej. Dalej pojawiają się cytowane za Perkowską argumenty o oddaleniu wilamowskiego od niemieckiego, użyciu języka polskiego w kościele czy deklarowania polskości przez wilamowskich studentów (Dziedzic \& Dziedzic, 2012, ss. 13-14). Argumenty te zostały co prawda rozwinięte przez autorów, ale forma tego rozwinięcia świadczy o ich braku znajomości specyfiki i historii Wilamowic:

[J]ako język powszechny modlitwy, nauczania i codziennej posługi [dominował] język polski. Matka Józefa Biby była w tym względzie jego pierwszą nauczycielką w nauczaniu języka polskiego, podstawowych zasad religii katolickiej i edukacji patriotycznej. Podobny klimat panował w zdecydowanej większości tamtejszych rodzin, skoro mieszkańcy Wilamowic, mimo tych odrębności i ówczesnych tamtejszych uwarunkowań politycznych, uważali się za Polaków (Dziedzic \& Dziedzic, 2012, s. 14).

Wyjaśniłem już, że klimat patriotyczny nie „panował w zdecydowanej większości” wilamowskich rodzin i wielu Wilamowian nie uważała się za Polaków. Nawet gdyby w domu Bibów rzeczywiście panował polski „duch patriotyczny", nie upoważniałoby to autorów do formułowania takich generalizacji. Natomiast w świetle dokumentów opublikowanych przez Wołczańskiego (Wołczański, 2016, ss. 412-413) także argument, że rodzina była polska, bo posłała syna do polskiej szkoły, wydaje się mniej przekonujący:

Gdy potem w czasie elementarnej nauki w szkółce miejscowej mały Józio niezwykłe okaże zdolności i chęci, matka poświęci wszystko, aby go dalej kształcić. Trzeba dziecko oddać z domu, ale dokąd skierować. Ojciec wybiera niemiecką szkołę w Białej, matce we śnie znowu Jan Kanty wskazuje swoje gniazdo rodzinne. To sprawę rozstrzyga (Wołczański, 2016, ss. 412-413). 
Zacytowany dokument potwierdza narrację o propolskim zaangażowaniu matki, lecz wyraźnie podważa tezę, że wybór polskiej szkoły był oczywisty. W tym kontekście słowa Kałużnego, że matka zaszczepiła w późniejszym arcybiskupie „potrzebę rozwoju religijnego i ducha patriotyzmu" (Kałużny, 2015, s. 27) wymagają dopowiedzenia, że chodzi o patriotyzm polski, a nie niemiecki czy wilamowski. Dla polskich autorów polskość rodziny Biöetuł-Mocków jest jednak niekwestionowaną oczywistością.

Wątek ojca, który nie podzielał propolskich poglądów żony i syna pojawia się w relacjach ustnych Wilamowian, a także w literaturze. Jego postawę podkreślały szczególnie osoby chcące zwrócić uwagę na niepolskie pochodzenie arcybiskupa. Niemiecki historyk Walter Kuhn pisał o nim jako o synu niemieckiego kolonisty, który „poprzez edukację w polskich szkołach stał się przekonanym Polakiem" (Kuhn, 1981, s. 362). Jednak również Polacy, którzy go znali wspominali o opozycji między ojcem - Niemcem a matką - Polką: „Wiem, że S[ługa] B[oży] pochodził z Wilamowic, nazywał się Biba, pochodził z rodziny kolonistów niemieckich, ale sam czuł się Polakiem i polskość swoją podkreślał. Matka jego była Polką i wychowała go jako Polaka" (Wołczański, 2016, s. 188).

Wydaje się, że marginalizacja roli ojca przez polskich autorów jest jednocześnie marginalizacją narracji o niepolskim aspekcie wychowania Józefa Biby. Z drugiej strony pisanie o jej świętych cnotach przywodzi na myśl przekonanie o szczególnej opiece Matki Bożej nad Polską, obecne w polskiej ideologii katolicko-narodowej (Jaskułowski, 2013, s. 40). Bilczewskiego cechował zresztą silny kult maryjny: „Kreuje się wyrazista postać arcybiskupa jako nadzwyczajnego czciciela Matki Bożej w narodzie polskim. Dostrzegał także wyjątkową rolę duchowieństwa i osób konsekrowanych w celebrowaniu kultu Bogurodzicy i kultywowaniu tradycji związanych z protekcją Maryi Panny nad Polską" (Szetelnicki, 2011, s. 234).

\section{Niemieccy koloniści czy polscy patrioci?}

Argumenty używane w procesie beatyfikacji i kanonizacji danej postaci są niezależne od jej narodowości. Bilczewski mógłby zostać uznany za świętego, nawet gdyby nie czuł się Polakiem. A jednak większość autorów tekstów prezentujących jego biografię zdecydowała się na udowadnianie polskości rodzinnej miejscowości, nawet kosztem naukowej rzetelności. Zdaniem Grażyny Kubicy, która analizowała podobny dyskurs w przypadku Ślązaków Cieszyńskich, taki sposób pisania świadczy nie tylko o niedoskonałości naukowego warsztatu autorów, ale może być przejawem hegemonii kulturowej, w której jako „naturalne” $i$ „normalne” przedstawiane są wyłącznie wartości grupy dominującej: „Badacze zazwyczaj przyjmują perspektywę katolicko-inteligenckich elit, nie 
zdając sobie z tego sprawy, i stosują ją jako neutralną, niewidoczną normę" (Kubica, 2011, s. 22). To „wtłaczanie do normy”, o którym pisała autorka (Kubica, 2011, s. 22), przejawia się w fabularyzacji i folkloryzacji poszczególnych wątków biografii Bilczewskiego. Dostosowywane były one głównie do toposów „ubogiego świętego" i „świętego Polaka”. Zwłaszcza ten ostatni wzmacnia „zbiorową opozycję między «nami» - Polakami-katolikami, a «nimi» - innymi, z której czerpie swą siłę nacjonalizm" (Jaskułowski \& Burszta, 2005, s. 21). Informacje o zamożności jego rodziców czy fakcie, że mieszkali w miejscowości, gdzie większość mieszkańców nie czuła się Polakami i rozmawiała w domu germańskim językiem tym treściom przeczyły, a więc zostały usunięte, zgodnie z zasadą, że „nacjonalizm korzysta z rozmaitych środków symbolicznych, dzięki którym stanowi rodzaj spoiwa między wielkim i anonimowym współczesnym społeczeństwem a tzw. zwykłym człowiekiem" (Jaskułowski \& Burszta, 2005, s. 21). Fabularyzacja i folkloryzacja powyższych opowieści przebiegła więc poprzez dostosowanie przekazu historii życia Bilczewskiego do polskiego dyskursu nacjonalistycznego. To dlatego współcześni hagiografowie przemilczeli, że w niemieckiej prasie istniały wzmianki o tym, że Bilczewski, będący symbolem polskości, pochodził z niemieckiej rodziny z okolic Bielska (por. Kozdon, 1910, s. 48), choć dostępne były one również w polskich źródłach przedwojennych (Bilczewski, b.d., s. 7, 1924, s. 6; Tarnawski, 1991, s. 8).

Topos „świętego Polaka” ma w hagiografiach Bilczewskiego dwa warianty. W jednym Bilczewski to „święty, który stał się Polakiem” niejako z własnego wyboru lub pod wpływem matki. Machniak i Tarnawski otwarcie przyznawali, że pochodził z niemieckiej kolonii, jednocześnie podkreślając, że był polskim patriotą. Tak też przedstawił siebie sam arcybiskup w swoich listach pasterskich. Podobnie pisali o nim, choć czasem z wyrzutem, niemieccy autorzy, sugerując, że Polakiem stał się nie poprzez gniazdo rodzinne, ale dalszą edukację.

W drugim wariancie polską patriotyczną postawę Bilczewskiego miało ukształtować "gniazdo rodzinne", a więc Wilamowice. Podobnie jak w przypadku źródeł analizowanych przez Kubicę, teksty te cechuje zarówno nierzetelność naukowa, jak i stosowanie nacjonalistycznego dyskursu polskiego hegemona jako neutralnej, niewidocznej normy. Toposy „świętego Polaka”, "ubogiego świętego" $i$ „zdolnego świętego" autorzy potwierdzili nie naukowymi dowodami (choć zapewne można takie było znaleźć), ale sfabularyzowanymi i sfolkloryzowanymi opowieściami, w których przemilczano elementy stojące z tymi toposami w sprzeczności. Takimi były na przykład wielowymiarowa, konstruowana w opozycji do polskości tożsamość Wilamowian, posługiwanie się w domu i szkole dwoma językami germańskimi czy plany ojca na posłanie go do niemieckiej szkoły. Pominięto również, niezgodne z obrazem Wilamowic jako „polskiego gniazda rodzinnego”, obecne w literaturze relacje o konfliktach Bilczewskiego 
z Wilamowianami na tle narodowościowym i próby polonizacji Wilamowian podjęte przez niego, gdy był już arcybiskupem (por. Wołczański, 2016, s. 271).

Przykład tekstów hagiograficznych o Józefie Bilczewskim pokazuje, że procesy fabularyzacji i folkloryzacji dotyczą nie tylko przekazów ustnych, ale obecne są również w tekstach hagiografów oraz naukowców. Poprzez przystosowanie, obiektywizację i eksponowanie symboli służą one interesom określonej grupy, podobnie jak opowieści z tradycji oralnej. W tym przypadku był to zabieg mitologizacji postaci Bilczewskiego, polegający głównie na polonizacji jego gniazda rodzinnego.

\section{Bibliografia}

Bilczewski, E. (b.d.). Pamiętniki. Cyfrowe archiwum Stowarzyszenia „Wilamowianie".

Bilczewski, J. (1924). Listy pasterskie, odezwy, kazania i mowy okolicznościowe (T.3). Biblioteka religijna.

Dziedzic, M., \&Dziedzic, S. (2012). Arcybiskup Józef Bilczewski. Wydawnictwo Apostolstwa Modlitwy.

Fic, M., Krzyżanowski, L., \& Meus, K. (2018). Wilamowice 1818-2018: Miasto i ludzie. Stowarzyszenie "Wilamowianie".

Filip, E. (2005). Flamandowie z Wilamowic? Stan badań. Bielsko-Bialskie Studia Muzealne, 2005(4), 146-198.

Grochowski, P. (2019). Ustne narracje o Holokauście: Między folklorem a historią mówioną. W P. Grochowski \& D. Czubala, O tym nie wolno mówić: Zagłada Żydów w opowieściach wspomnieniowych ze zbiorów Dionizjusza Czubali (ss. 7-36). Wydawnictwo Naukowe Uniwersytetu Mikołaja Kopernika w Toruniu.

Hajduk-Nijakowska, J. (2016). Doświadczanie pamięci: Folklorystyczny kontekst opowieści wspomnieniowych. Uniwersytet Opolski.

Hammersley, M., \& Atkinson, P. (2000). Metody badań terenowych (S. Dymczyk, Tłum.). Zysk i S-ka. Jaskułowski, K. (2013). W imię Boga i narodu: Szkic o relacjach między religią a nacjonalizmem. W M. Pycińska \& K. Wiciarz (Red.), Nacjonalizm i religia: Refleksje nad uniwersalnością pojęći teorii w kontekście badań Azji i Afryki Północnej (ss. 23-43). Unum.

Jaskułowski, K., \& Burszta, W. J. (2005). Mity, symbole i bohaterowie narodowi z perspektywy antropologicznej, W J. Haubold-Stolle \& B. Linek (Red.), Górny Ślask wyobrażony: Wokół mitów, symboli i bohaterów narodowych (ss. 17-35). Instytut Śląski w Opolu; Herder Institut.

Kałużny, J. C. (2015). Święty Józef Bilczewski badacz starożytności chrześcijańskiej i jego dyscyplinarna metoda w świetle nieznanych materiałów źródłowych z lat 1885-1900. Wydawnictwo Bł. Jakuba Strzemię Archidiecezji Lwowskiej ob. łac.

Koperek, S. (2003). Pasterz i liturg. W J. Wołczański (Red.), Błogosławiony Józef Bilczewski arcybiskup metropolita Iwowski obrzq̨dku łacińskiego: Sesja naukowa na Uniwersytecie Jagiellońskim, Kraków, 4-5 czerwca 2002 (ss. 71-86). Wydawnictwo Naukowe Papieskiej Akademii Teologicznej w Krakowie. 
Kozdon, J. (1910). Über die Sonderstellung der schlesischen Polen, die nationalen Verhältnisse und die allpolnische Propaganda in Ostschlesien: Rede des Landtagsabg. Kozdon in der Budgetdebatte des schlesischen Landtages (44. Sitzung) am 8. November 1910. Schlesische Volkspartei. Śląska Biblioteka Cyfrowa. http://www.sbc.org.pl/Content/430689/Publikacja-KC-8526.pdf

Król, T. (2018). Powojenne wywózki i wysiedlenia: Przypadek Wilamowic [Praca magisterska, Wydział "Artes Liberales", Uniwersytet Warszawski]. Archiwum Stowarzyszenia "Wilamowianie".

Król, T. (2020). Die Wilmes-Wiener. Bielitz-Bialaer Rundbrief aus Hannover, 58, 31-45.

Kubica, G. (2011). Ślaskość i protestantyzm: Antropologiczne studia o Śląsku Cieszyńskim, proza, fotografia. Wydawnictwo Uniwersytetu Jagiellońskiego. https://ruj.uj.edu.pl/xmlui/handle/item/64047

Kuhn, W. (1981). Geschichte der deutschen Sprachinsel Bielitz (Schlesien). Holzner Verlag.

Latosiński, J. (1909). Monografia miasteczka Wilamowic: Na podstawie źródeł autentycznych: $Z$ ilustracyami i mapka. Drukarnia literacka pod zarządem L. K. Górskiego. http://dlibra.umcs .lublin.pl/publication/5051

Liber vitorum. (1831-1868). Księga metrykalna w Archiwum Parafii Wilamowice, Wilamowice. Machniak, J. (2001). Abp Józef Bilczewski: Święci wśród nas. Wydawnictwo św. Stanisława BM.

Meus, K. (2018). Część pierwsza: Lata 1818-1914. W M. Fic, L. Krzyżanowski, \& K. Meus, Wilamowice 1818-2018: Miasto i ludzie (ss. 15-138). Stowarzyszenie "Wilamowianie”.

Neels, R. (2012). De nakende taaldood van het Wymysojer, een Germaans taaleiland in Zuid-Polen: Een socuilinguïstische analyse [Niepublikowana rozprawa doktorska]. Katolieke Universiteit Leuven.

Perkowska, U. (2003). Młodość i lata krakowskie Józefa Bilczewskiego. W J. Wołczański (Red.), Błogosławiony Józef Bilczewski arcybiskup metropolita Iwowski obrzq̨dku łacińskiego: Sesja naukowa na Uniwersytecie Jagiellońskim, Kraków, 4-5 czerwca 2002 (ss. 131-149). Wydawnictwo Naukowe Papieskiej Akademii Teologicznej w Krakowie.

Prokop, K. R. (2010). Arcybiskupi haliccy i Iwowscy obrzq̨dku łacińskiego: Szkice biograficzne. Ośrodek „Wołanie z Wołynia”.

Rosner, O. (1977). Chronik von Wilmesau. Rękopis w archiwum Stowarzyszenia "Wilamowianie". Schauber, V., \& Schindler, H. M. (2008). Ilustrowany leksykon świętych (P. Tkaczyk \& R. Zajączkowski, Tłum.). Wydawnictwo Jedność.

Szetelnicki, W. (2011). Postać św. Józefa Bilczewskiego arcybiskupa i metropolity Iwowskiego obrządku łacińskiego w świetle kroniki klasztoru Panien Benedyktynek łacińskich Iwowskich. Perspectiva - Legnickie Studia Teologiczno-Historyczne, 10(1(18)), 226-260. http://perspectiva.pl /pdf/p18/13Szetelnicki.pdf

Tarnawski, M. (1991). Arcybiskup Józef Bilczewski: Krótki rys życia i prac. Tow. „Bibljoteka Religijna”. Instytut Teologiczny Księży Misjonarzy. (Oryginalna praca opublikowana 1924).

Urban, W. (1977). Sługa Boży Józef Bilczewski: Arcybiskup-Metropolita Lwowski 1860-1923. [b.w.].

Wicherkiewicz, T., \& Zieniukowa, J. (2001). Język i piśmiennictwo. W A. Barciak (Red.), Wilamowice: Przyroda, historia, język, kultura oraz społeczeństwo miasta i gminy (ss. 487-578). Urząd Gminy. 
Wicherkiewicz, T. (2003). The making of a language: The case of the idiom of Wilamowice, southern Poland. Mouton de Gruyter. https://doi.org/10.1515/9783110905403

Wicherkiewicz, T., Król, T., \& Olko, J. (2017). Awakening the language and speakers community of Wymysiöeryś. European Review, 26(1), 179-191. https://doi.org/10.1017/S1062798717000424

Wołczański, J. (2003). Biogram i bibliografia prac drukowanych błogosławionego Józefa Bilczewskiego za lata 1888-1929. W J. Wołczański (Red.), Błogosławiony Józef Bilczewski arcybiskup metropolita Iwowski obrządku łacińskiego: Sesja naukowa na Uniwersytecie Jagiellońskim, Kraków, 4-5 czerwca 2002 (ss. 17-47). Wydawnictwo Naukowe Papieskiej Akademii Teologicznej w Krakowie.

Wołczański, J. (Red.). (2016). Nic dla siebie, wszystko dla Boga i bliźniego: Święty arcybiskup Józef Bilczewski we wspomnieniach. Wydawnictwo Bł. Jakuba Strzemię Archidiecezji Lwowskiej Ob. Łac. Zajączek, E. (1929). Ś.p. Józef Latosiński. Młody Narodowiec, 1929(6), 9-10. https://jbc.bj.uj.edu.pl /dlibra/publication/323197/edition/309206/content

\section{A Polish Patriot from a German Colony: An Analysis of Hagiographic Texts about Józef Bilczewski}

The town of Wilamowice was established in the thirteenth century by settlers of Germanic origin who arrived from Western Europe. The Germanic language Wymysorys and other elements of culture they developed are present in Wilamowice until today.

The town is the birthplace of Józef Biba, the Archbishop of Lwów (today: Lviv) and a saint of the Catholic Church, born in 1860. The authors of his biographies have not only stressed his virtues and miracles, but also devoted considerable attention to the Polishness of his family home, which, as they write, involved the Polish patriotic attitude of his parents and Polish as his mother tongue. Apart from his family, also the entire Wilamowice was presented as "a nest of Polish patriotism". Yet, at that time most Vilamovians spoke Wymysorys at home and some of them did not know Polish at all. They had their specific, multidimensional identity, constructed in opposition to Germanness and Polishness. In censuses they declared that their mother tongue and nationality was German.

The texts where the authors attempt to prove the Polishness of Bilczewski are an example of Polish nationalist discourse, which considers the values of the dominant group to be "neutral" and "normal". One case in point are the topoi of "a saint Pole" and "a poor saint", considered "obvious" by Polish authors. To make them more credible, they supported them with fabularised and folklorised stories, rewritten again and again in new texts they published. They rarely referred to sources, and if they did, it was without adequate critical apparatus. This article is an attempt to present the fabularisation and folklorisation of particular stories, which led to the development of one version shared by the community.

\section{Keywords:}

Wilamowice; Wymysorys language; Józef Bilczewski; fabularisation; folklorisation; hagiography 


\title{
Polski patriota z niemieckiej kolonii. Analiza tekstów hagiograficznych o Józefie Bilczewskim
}

\begin{abstract}
Wilamowice to miasto założone w XIII wieku przez osadników germańskiego pochodzenia przybyłych z zachodniej Europy. Do dzisiaj zachował się germański język wymysiöeryś oraz stroje i inne elementy kultury wytworzonej przez osadników. Wilamowianie to grupa etniczna, którą cechują odmienny język, strój, świadomość własnej odrębności (zarówno od Niemców, jak i Polaków), a także mit wspólnego (flamandzkiego lub holenderskiego) pochodzenia oraz wspólnota pamięci. Tożsamość Wilamowian była wielowymiarowa, gdyż starali się być lojalni wobec każdego organizmu państwowego, w którym się znaleźli, a jednocześnie zachowywali swoją tożsamość i ją manifestowali.

W tej miejscowości urodził się w 1860 roku Józef Biba, późniejszy arcybiskup lwowski Józef Bilczewski oraz święty Kościoła rzymskokatolickiego. Autorzy jego biografii, oprócz cnót i cudów mających potwierdzać jego świętość, wiele miejsca poświęcili podkreślaniu polskości jego domu rodzinnego. Składać miała się na nią zarówno polska patriotyczna postawa rodziców, jak i polski jako język ojczysty. Jako gniazdo polskiego patriotyzmu przedstawiono całe Wilamowice. Tymczasem wówczas większość Wilamowian mówiła w domu wyłącznie po wilamowsku, niektórzy nie znali języka polskiego w ogóle. Ponieważ swojej specyficznej tożsamości nie mogli podać w spisach powszechnych, zamiast niej podawali język ojczysty i narodowość niemiecką.

Teksty, w których autorzy udowadniają polskość miejsca urodzenia Bilczewskiego, są przykładem polskiego dyskursu nacjonalistycznego, który za "naturalne” i „normalne” uznaje wyłącznie wartości grupy dominującej. Taką „oczy wistością” są dla polskich autorów toposy „świętego Polaka” oraz „ubogiego świętego". Aby je uwiarygodnić, stosowali sfabularyzowane i sfolkloryzowane opowieści, powtarzane w kolejnych tekstach drukowanych. Rzadko powoływali się na źródła, a jeśli już, to często bez odpowiedniego aparatu krytycznego. W tekście staram się pokazać, jak poszczególne opowieści ulegały fabularyzacji i folkloryzacji, wskutek czego stworzona została wspólnotowa wersja.
\end{abstract}

\section{Słowa kluczowe:}

Wilamowice; język wilamowski; Józef Bilczewski; fabularyzacja; folkloryzacja; hagiografia

\section{Citation:}

Król, T. (2021). Polski patriota z niemieckiej kolonii: Analiza tekstów hagiograficznych o Józefie Bilczewskim. Adeptus, 2021(18), Article 2595. https://doi.org/10.11649/a.2595

\section{Publication History:}

Received: 2021-06-24; Accepted: 2021-12-23; Published: 2022-01-17 